\title{
The Effect of Trust and Ease of Use of E-filling on Tax Compliance in the Era of Big Data Analytics
}

\author{
Ida Suriya Ismail ${ }^{1}$, Sara Naquia Hanim Shaharuddin ${ }^{2}$, Nur Asma Husna Shahroni ${ }^{3}$, Nur \\ Mutmainnah Ibrahim ${ }^{4}$, Ummi Raihana Mohd Sani ${ }^{5}$ \\ \{idasu634@uitm.edu.my¹, sara14381@gmail.com² ${ }^{2}$ husnashah95@gmail.com³ \\ mutmainnah.ibrahim@gmail.com ${ }^{4}$, raihanasani17@gmail.com $\left.{ }^{5}\right\}$
}

Faculty of Accountancy, Universiti Teknologi MARA, Kampus Puncak Alam, 42300 Kuala Selangor, Selangor, Malaysia ${ }^{1}$, Faculty of Accountancy, Universiti Teknologi MARA, Kampus Shah Alam, 40450

Shah Alam, Slengor, Malaysia $2,3,4,5$

\begin{abstract}
The emergence of Big Data allows extremely large data sets to be captured and analysed computationally. The existent of e-filling system in Malaysia contribute to a large taxpayers' information that could be analysed easily by tax authorities. Therefore, taxpayers may have trust issues that will lead to their tax compliance levels. This study aims to examine the impact of trust issues and ease of use of the e-filing system on tax compliance in the era of Big Data Analaytics. Data is collected using online questionnaires. 70 respondents have been analyzed. The results show that taxpayers have significant positive trust of the e-filing and positive perception towards the ease of use of the system. Big Data also have an impact to the tax compliance among taxpayers. These findings are expected to give insight to tax authorities in planning their activities to increase taxpayers' compliance in the era of big data analytics.
\end{abstract}

Keywords: Trust, Ease of Use. E-filling, Tax Compliancelease, Big Data.

\section{Introduction}

The emergence of Big Data allows extremely large data sets to be captured and analysed computationally to reveal patterns, trends and associations, as well as human interactions. Nowadays either individual or business is increasingly impacted by data analytics. Every aspect of any transactions is impacted by enhancing computing power and improving analytical tools. Taxation issues are not behind in this matter. In line with the online revolution, E-filing (electronic filing of taxation) that has been introduced since 2006 is a good online portal for taxpayers to submit their tax returns, make payments and receive tax refunds. The existent of efilling system contribute to a large taxpayers' information that could be captured and analysed with the adoption of Big Data analytics. Since the taxpayers' private and confidential data is being captured and held by the tax authorities through the e-filing system, taxpayers may have trust issues that will lead to their tax compliance levels.

[1] has found that that the adoption of technology does impact the tax compliance levels of the taxpayers when there is a positive relationship between the adoption of technology and the tax compliance levels. However, the evolution of online information motivates this study to examine whether Big Data does impact taxpayers' tax compliance level or not. Therefore, the main objective of this study is to examine the impact of Big Data towards taxpayers' tax 
compliance where two main areas are investigated including trust issues and ease of use of the e-filing system. In order to investigate these issues, e-filing system was used as a medium in connecting the significance of Big Data and taxpayers tax compliance.

The significance of this study can be seen in at least two viewpoints. Firstly, as far as it can be ascertained, there is a limited number of researches have been done concerning the impact of Big Data and tax compliance since only in 21st century the evolution of Big Data is having major impact on taxation. Even the tax authorities realized that innovation in the field of data and analytics has provided new tools to help close the tax gap, collect data and share it across borders, and improve the efficiency of the tax collection function [2]. This study aims to fill this gap. Second, this study focuses on country where the progress of becoming a big data and analytics (BDA) is still in the process before it becomes the BDA hub in Southeast Asia. Therefore, it expected that Big Data impact towards tax compliance is still in the early stages.

\section{Literature Review}

\subsection{Big Data and E-Filling}

Under the explosive increase of global data, the term of big data is mainly used to describe enormous datasets. Compared with traditional datasets, big data typically includes masses of unstructured data that need more real-time analysis. In addition, big data also brings about new opportunities for discovering new values, helps responsible person to gain an in-depth understanding of the hidden values, and also incurs new challenges such as how to effectively organize and manage such datasets [3]. International Data Corporations defines Big Data technologies as a new generation of technologies and architectures, designed to economically extract value from very large volumes of a wide variety of data by enabling high-velocity capture, discovery, and/or analysis. There are three main characteristics of Big Data, which are the data itself, the analytics of the data, and the presentation of the results of the analytics. Then there are the products and services that can be wrapped around one or all of these Big Data elements.

This technological advancement needs to make it easier for taxpayers to comply with their tax obligations if it increases the accessibility level as well as the amount of information available, widening the range of payment modalities, reducing the need for taxpayers to visit the office and shortening waiting times for those taxpayers who need helps [1]. As such this will lead to better tax compliance. According to [4], e-filing can improve the tax return filing process for the taxpayers and at the same time reduce cost for both the taxpayers as well as the tax agencies. The e-filing system are able to capture taxpayer's information electronically and able to integrate the data from other government agencies automatically. For example, government officer's gross salary is automatically captured in the e-filing system without the need for them to manually key in the amount resulting to ease of use to the users. These are all made successful by the usage of Big Data and internet functions. Although Malaysian taxpayers has been able to use electronic filing since 2006, the number of taxpayers using e-filing to submit their tax returns is still significantly below the IRB target of full adoption [5]. Moving forwards, [6] stated in The Star News, the usage of e-filing has increased steadily of 9.15\% in May 2019 compared to the same period in the previous year. Even though an increase is being seen, the pathway to full adoption of E-filing by the Malaysian taxpayers are still far. 


\subsection{Tax Compliance}

Tax compliance can be defined as the timely filling and reporting of required tax information, the correct self-assessment of taxes owed, and the timely payment of those taxes without enforcement action [7]. Besides, the opinions of [8] indicate that "compliance with reporting requirements means that tax payers files are all required tax returns at proper time and that the returns accurately report tax liability in accordance with the internal Revenue Code, regulations, and court decision applicable at the time return is filed".

Taxpayers non-compliance has resulted to larger tax gap which is the difference between what the taxpayers pay to the government and what they would owe if they are fully compliant with the tax laws. According to [9], over time, the tax gap has grown as a result of noncompliance. Tax compliance can mainly be achieved in the event that majority of taxpayers and potential taxpayers voluntarily file their tax returns and pay resultant tax liabilities as per the national tax laws enforced without the intervention of the tax authorities through enforcement and punishment. Ensuring and building a high level of compliance will need a wide range of technology especially with regards to computers and internet, as well as effectiveness of tax administration to detect and punish people who attempt to evade taxes.

In order to minimize taxpayers' non-compliance, the trust issues includes both trust in the government and trust in the internet should be well developed. Trust in the government agency providing the electronic service hinges upon the belief that it is capable of providing electronic tax services effectively and confidentially [10]. Taxpayers must believe that the government has deployed the necessary resources and possesses the knowledge, skills and ability to deliver reliable and secure internet-based services. On the other hand, trust in the internet refers to an individual's perception about transmitting sensitive information over the internet as well as conducting transactions using the internet. The use of the internet to submit a tax return requires a taxpayer to submit very personal and sensitive information via the internet which is captured as Big Data. There is the potential that this information could be intercepted and manipulated [10]. In determining whether with the intervention of Big Data in the e-filing will affect the taxpayers tax compliance, the issue of trust need to be examined as this study expect that higher trust will increase tax compliance.

Besides trust, perceived usefulness is a strong determinant of a user acceptance towards the system as prposed by [11] using the Technological Acceptance Model (TAM). Perceived ease of use is an internal belief that an individual holds about the mental effort involved in using a system. To determine whether taxpayers are able to comply with tax laws, taxpayers need to accept the filing system together with the result to be more compliance. [10] argues that taxpayers will not consider e-filing to submit their tax returns if the system is too complex to navigate. In addition, [9] claimed that knowledge (or understanding) that taxpayers have about the tax system will affect their tax compliance. Given a complex and uncertain tax system, taxpayers need to rely on tax practitioners or tax-preparation software. In other words, a complicated tax system tends to increase non-compliance while a simpler tax system with better administrative service and information will reduce non-compliance.

Taxpayers' intention to submit their tax returns may be affected by the need to be assured of the ability to manage and control the electronic application system e-filing. Therefore, this study examine whether Big Data plays an important part in motivating taxpayers to voluntarily use the electronic system. 


\section{Methodology and Data Analysis}

The population of this study is the individual workers in Klang Valley, Malaysia and the sample are chosen using the Simple Random Sampling since every person in the population has an equal chance of being selected as a subject. Data collection for this study consists of primary data which is collected using electronic and online questionnaires using simple random sampling method. The respondents must be individual who working in either private or public sector. The questionnaires were sent out and this study manage to get 70 respondents. Google form has been used and this questionnaire has options to make all questions compulsory to be answered. The online Google Form has helped us to easily analyse the data and automatically transfer the result into the graphical chart. The questionnaires used 5 Point Likert Scale. $1=$ Strongly Disagree, 2 = Disagree, 3 = Neutral, $4=$ Agree, $5=$ Strongly Agree.

Questionnaire design consists of two parts. Part A is demographic information where the question about gender, age and highest education background, line of work and salary range is being captured. Part B regarding the tax compliance which is consist of three sections which is the first Big data and E-filling where by related to tax compliance of the big data and e-filing, while for the second is Big data trust that related to the taxpayer's trust on system regarding using Big data. For the last section is Perceive Ease of Use of big data. This Part B focus on how these three sections will impact on tax compliance.

\section{Results and Discussion}

\subsection{Demographic Information}

The total sample consisted 48 females and 22 males. Most of the respondents (31\%) from the age between 36 to 40 years old, $19 \%$ from the range of more than 40 years old, $17 \%$ from the range of 31 to 35 years old and below 25 years old while only $16 \%$ between the range of 26 to 30 years old. A high percentage $(72.9 \%)$ of participants held a university degree and professional qualifications, $22.9 \%$ held a master qualification, $3 \%$ held SPM qualification and below while only $1 \%$ held a doctorate qualification. Based on line of work, majority of the respondents $(31.4 \%)$ are from line of education, $13 \%$ from finance, $11 \%$ from information, communication and technology, $9 \%$ from engineering, $1 \%$ from healthcare and retails while $27 \%$ indicated other line of work. $40 \%$ reported a monthly salary between RM2,501 to RM5,000, 32.9\% reported a monthly salary between RM7,501 to RM10,000, 17.1\% reported a monthly salary between RM5,001 to RM7,500, and 10\% reported a monthly salary below RM2,500. $78.6 \%$ of the respondents claimed that they paid tax while $21.4 \%$ did not pay tax.

\subsection{Regression Analysis}

The analysis has been done using the SPSS software version 23. In order to understand the characteristics of the data used in this study, this section presents the descriptive results of the data. Table 1 presents descriptive information on tax compliance, big data trust and big data ease of use. Mean values for tax compliance, big data trust and big data ease of use are 31.01, 25.49 and 19.00 resepctively. All the figures are on the high side indicating that respondents have high tax compliance, trust and perception of ease of use of Big Data on e-filing.

This study conducted normality tests to determine whether the data set has normal distribution. This study decided to apply statistical method in evaluating normality specifically 
using two numerical measures of shape namely skewness and kurtosis. The data set would be considered as normal distribution when the statistical number for skewness is within +/- 1.96 and kurtosis of $+/-3.0$ [12]. The results from the normality test carried out on skewness and kurtosis indicates that all data are normally distributed.

Table 1. Descriptive Statistics

\begin{tabular}{lllllll}
\hline & Mean & Minimum & Maximum & Stad Deviation & Skewness & Kurtosis \\
\hline Tax Compliance & 31.01 & 21 & 25 & 4.261 & -0.444 & -0.543 \\
Big Data Trust & 25.49 & 16 & 30 & 3.492 & -0.096 & -0.345 \\
Big Data Ease of & 19.00 & 11 & 35 & 3.041 & -0.785 & -0.424 \\
Use & & & & & & \\
\hline
\end{tabular}

Pearson correlation coefficient was used to analyse the relationship before running the multiple regression analysis. This study tested the multicollinearity assumption using Pearson correlation. According to [13], multicollinearity can be identified if the squared multiple correlations are near or equal to 1 . There is no multicollinearity issues between the varibles since the value are not near to 1 . The linear regression results are presented in Table 2 with tax compliance as a dependent variable while big data trust and big data ease of use as an independent variable. As shown in the table, big data trust have relatively positive relationship with tax compliance at $\mathrm{p}<0.01$. The results confirm that taxpayers who trust the online system tend to comply with tax laws and regulations. Besides that, the ease of use also has a positive relationship to tax compliance and it is significant at $p<0.10$. This indicates that when taxpayers think that the system is easy to be used, then, their tax compliance will increase.

Table 2. Regression Results

\begin{tabular}{lcc}
\hline & \multicolumn{2}{c}{ Dependent variable: Tax Compliance } \\
\cline { 2 - 3 } & Beta & t-value \\
\cline { 2 - 3 } Constant & 7.244 & $2.363^{* *}$ \\
Big Data Trust & 0.627 & $6.687^{* * *}$ \\
Big Data Ease of use & 0.161 & $1.714^{*}$ \\
Adjusted $R^{2}$ & & \\
$F$-Statistics & & 0.479 \\
$N$ & \multicolumn{3}{c}{} \\
\hline
\end{tabular}

\section{Conclusion}

From the analysis of this study, it can be concluded that the respondents who are also taxpayers contributing to Malaysian Inland Revenue Board do have significant positive trust of the e-filing system and significant positive perception towards the ease of use of the e-filing system that has been executed since 2006. This has led to the increase in tax compliance using the e-filing system as the taxpayers are not burden by technicalities and complicated system. 
Since the usage of e-filing involve the presence of Big Data, this means that Big Data do positively impact the intention to re-use E-filing by the taxpayers. This finding supports the previous study done by [14] when they found that the taxpayers who are satisfied with the efiling system would use it again in the next filing session.

The usage of Big Data has helped Malaysian Inland Revenue Board (IRBM) to improve tax collection from Malaysian taxpayers. In addition, this study also found that Big Data does have an impact to the tax compliance among Malaysian taxpayers. The findings of this study further strengthern the IRBM's desire to use Big Data analytical tools in tax administration since it could increase government's revenue, reduce cost and improve tax compliance. Future researches may analyse other areas of Big Data usage or Big Data Analytics among Malaysian taxpayers in line with the change of technological advancement.

\section{Implications/Limitations and Suggestions for Future Research}

The limitation of this study is the small sample size since the study only focus on Klang Valley. Nevertheless, it is sufficient to represent the population of the study. This study followed the suggestion by [15] as they claimed "the results show that only a small sample size at level two (meaning a sample of 50 or less) leads to biased estimates of the second-level standard errors." Therefore, in the case where sample size is more than 50 , the results are accurate and unbiased. However, this study suggests for a higher sample size for future studies. Another limitation is that this study only focus on two variables that are trust and ease of use in which other variables such as tax audit and penalties could be further explored in the future. Besides, future study could interview IRB staf regarding the usefulness og big data in motivating taxpayers' compliance behaviour.

Acknowledgement. This research was supported by Faculty of Accountancy, Universiti Teknologi MARA, Campus Puncak Alam. We thank our colleagues from Faculty of Accountancy who provide insight and expertise that greatly assisted the research.

\section{References}

[1] Kamau, S. K.: The adoption of technology as strategic tool in enhancing tax compliance in Kenya: A case study of large taxpayers of Kenya Revenue Authority," United States International University Africa. (2014)

[2] Gillis, T. H. and Stephanny, P.: Going beyond the data: tax data is big data. Bloomberg BNA: Tax Planning International: Indirect Taxes. (2014)

[3] Chen, M., Mao, S. and Liu, Y.: Big data: A survey. Vol. 19, No. 2, pp. 171-209. Mobile. Networks And Applications. (2014)

[4] Fu, J. R., Farn, C. K. and Chao, W. P.: Acceptance of electronic tax filing: A study of taxpayer intentions.Vol. 43, pp. 109-126. Information \& Management. (2006)

[5] Tan, T. H. and Foo, Y. F.: Predicting Taxpayers' Intentions of Adopting Electronic TaxFiling (E-Filing) in Malaysia. Vol. 19, No. 2, pp. 59-71. Journal of Accounting, Business \& Management. (2012)

[6] Zainal, F.: More people use IRB'S Efiling system. The Star Online. (2019)

[7] Allink, M. and Kommer, V.: Organizational structure and management of Tax Administrations. Handbook f. Inter-American Center of Tax Administrations. (2010) 
[8] Hasseldine, J.: How Do Revenue Audit Effect Tax Payer Compliance?. Vol. 47. Anonymous. (1993)

[9] Alm, J., Beebe, J., Kirsch, M. S., Marian, O. Y. and Soled, J. A.: New Technologies and the Evolution of Tax Compliance. Vol. 39, No. 3. Virginia Tax Review. (2020)

[10] Carter, L., Schaupp, L. C. and McBride, M. E.: The US e-file initiative: An investigation of the antecedents to adoption from the individual taxpayers' perspective. Vol. 7, No. 3, pp. 219. e-Service Journal: A Journal of Electronic Services in the Public and Private Sectors. (2011) [11] Davis, F. D.: Perceived usefulness, perceived ease of use, and user acceptance of information technology. Vol 13, No. 3, pp. 319-340. MIS Quarterly. (1989)

[12] Sulong, Z. and Nor, F. M.: Dividends, Ownership Structure and Board Governance On Firm Value: Empirical Evidences From Malaysian Listed Firm. Vol. 7, No. 2, pp. 55-94. Management \& Accounting Review. (2008)

[13] Coakes, S. J. and Steed, L. G.: SPSS Analysis without Anguish, 14.0. John Wiley \& Sons Ltd. (2007)

[14] Puthur, J.K., Lakshman, M. and George, A. P.: Tax payer Satisfaction and Intention to Reuse Government site for E-filing. Vol. 8, No. 1, pp. 46-59. Indore Management Journal. (2016) [15] Maas, C. J. M. and Hox, J. J.: Sufficient Sample Sizes for Multilevel Modeling. Vol. 1, No. 3, pp. 86-92. Methodology: European Journal of Research Methods for the Behavioral. and Social Sciences. (2005). doi: 10.1027/1614-1881.1.3.86. 